\title{
Effect of Platycodin D on Airway MUC5AC Mucin Production and Gene Expression Induced by Growth Factor and Proinflammatory Factor
}

\author{
Hyun Jae Lee ${ }^{1, a}$, Su Yel LeE ${ }^{1, a}$, Byeong Kyou Jeon ${ }^{2}$, Jae Woo LeE ${ }^{3}$, \\ Young Sik KIm ${ }^{4}$, Mi Nam LEE ${ }^{1}$, and Choong Jae LEE ${ }^{1, *}$ \\ ${ }^{1}$ Department of Pharmacology, School of Medicine, Chungnam National University, Daejeon 301-131, \\ ${ }^{2}$ Department of Radiologic Technology, Daegu Health College, Daegu 702-722, ${ }^{3}$ LG Life Science, Seoul 150-721, \\ and ${ }^{4}$ Department of Pharmaceutical Sciences, College of Pharmacy, Seoul National University, Seoul 151-742, Republic of Korea
}

(Received July 8, 2010; Revised July 19, 2010; Accepted July 19, 2010)

\begin{abstract}
In this study, we tried to investigate whether platycodin D significantly affects MUC5AC mucin production and gene expression induced by epidermal growth factor (EGF), phorbol ester (PMA) and tumor necrosis factor- $\alpha$ (TNF- $\alpha$ ) from human airway epithelial cells. Confluent NCl-H292 cells were pretreated with varying concentrations of platycodin D for $30 \mathrm{~min}$ and then stimulated with EGF, PMA and TNF- $\alpha$ for 24h, respectively. MUC5AC mucin gene expression and mucin protein production were measured by RT-PCR and ELISA. The results were as follows: (1) Platycodin $D$ was found to inhibit the production of MUC5AC mucin protein induced by EGF, PMA, and TNF- $\alpha$, respectively. (2) It also inhibited the expression of MUC5AC mucin gene induced by the same inducers. These results suggest that platycodin $D$ can regulate mucin gene expression and production of mucin protein, by directly acting on human airway epithelial cells.
\end{abstract}

Keywords: Airway mucin, MUC5AC, Platycodin D

\section{INTRODUCTION}

Airway mucus is very important in defensive action against invading pathogenic microorganisms, chemicals and particles. This defensive action of airway mucus is attributed to the physicochemical property of mucins i.e. viscoelasticity. Mucins are multimillion dalton glycoproteins present in the airway mucus and produced by goblet cells in the surface epithelium as well as mucous cells in the submucosal gland. However, hypersecretion of airway mucus is one of the major symptoms associated with severe pulmonary diseases including asthma, chronic bronchitis, cystic fibrosis and bronchiectasis (Ellis, 1985). Therefore, we suggest it is valuable to find the potential activity of regulating (inhibiting) the excess mucin secretion (production) by the compounds derived from various medicinal plants. We have tried to investigate the possible activities of some natural products on mucin secretion from cultured airway epithelial cells. As a result of our trial, we previously re-

*Corresponding author

Tel: +82-42-580-8255 Fax: +82-42-585-6627

E-mail: LCJ123@cnu.ac.kr

${ }^{a}$ These two authors equally contributed to this work. ported that several natural compounds affected mucin secretion and/or production from airway epithelial cells (Lee et al., 2003, 2004a, 2004b; Heo et al., 2007a, 2007b, 2009). According to traditional oriental medicine, the root of Platycodon grandiflorum has been used for regulating pulmonary inflammatory diseases (Jang, 2003). Platycodin D (PD), a compound isolated from the root of Platycodon grandiflorum, was reported to have various biological effects including anticancer effect (Kim et al., 2001; Ahn et al., 2006; Chung et al., 2008; Kim et al., 2008; Yu and Kim, 2010). Platycodin $D$ induced apoptosis in human breast cancer cells (Yu and Kim, 2010). In immortalized keratinocytes, it induced apoptosis through activation of nuclear factor-kappaB (Ahn et al., 2006) and decreased telomerase activity in human leukemia cells (Kim et al., 2008). Platycodin D inhibited the production of prostaglandin E2 (Kim et al., 2001) and showed anti-inflammatory activity by inhibition of nuclear factor-kappaB pathway (Chung et al., 2008). Also, Shin and his colleagues reported that platycodin $\mathrm{D}$ and platycodin $\mathrm{D} 3$ increased mucin release from primary rat and hamster tracheal surface epithelial cell culture and also from intact rat trachea upon nebulization (Shin et al., 2002). However, to the best of our knowledge, 
there is no report about the potential effect of platycodin $D$ on airway mucin production and/or gene expression from human airway epithelial cells. Therefore, in this study, we investigated whether platycodin $\mathrm{D}$ affect mucin production and gene expression from $\mathrm{NCl}-\mathrm{H} 292$ cells, a human pulmonary mucoepidermoid cell line.

\section{MATERIALS AND METHODS}

\section{Materials}

All the chemicals and reagents used in this experiment were purchased from Sigma (St. Louis, MO, USA) unless otherwise specified. Platycodin D was isolated, purified and identified by analytical chemists in Research Institute of Natural Products of Seoul National University (Seoul, Korea).

\section{Cell culture}

$\mathrm{NCl}-\mathrm{H} 292$ cells, a human pulmonary mucoepidermoid carcinoma cell line, were purchased from the American Type Culture Collection (ATCC, Manassas, VA, U.S.A.) and cultured in RPMI 1640 supplemented with $10 \%$ fetal bovine serum (FBS) in the presence of penicillin (100 units $/ \mathrm{ml})$, streptomycin $(100 \mu \mathrm{g} / \mathrm{ml})$ and HEPES $(25 \mathrm{mM})$ at $37^{\circ} \mathrm{C}$ in a humidified, $5 \% \mathrm{CO}_{2} / 95 \%$ air, water-jacketed incubator. For serum deprivation, confluent cells were washed twice with phosphate-buffered saline (PBS) and recultured in RPMI 1640 with $0.2 \%$ fetal bovine serum for $24 \mathrm{~h}$.

\section{Treatment of cells with platycodin D}

After $24 \mathrm{~h}$ of serum deprivation, cells were pretreated with platycodin $\mathrm{D}(1,10$ and $100 \mu \mathrm{M})$ for $30 \mathrm{~min}$ and treated with EGF (25 ng/ml), PMA (10 ng/ml) and TNF- $\alpha(0.2$ $\mathrm{nM}$ ) for $24 \mathrm{~h}$ in serum-free RPMI 1640, respectively. Platycodin $\mathrm{D}$ was dissolved in dimethylsulfoxide, diluted in PBS and treated in culture medium (final concentrations of dimethylsulfoxide were $0.5 \%$ ). Culture medium, PBS solution and $0.5 \%$ dimethylsulfoxide in medium did not affect mucin production and gene expression from $\mathrm{NCl}-\mathrm{H} 292$ cells. After $24 \mathrm{~h}$, cells were lysed with buffer solution containing $20 \mathrm{mM}$ Tris, 0.5\% NP-40, $250 \mathrm{mM} \mathrm{NaCl}, 3 \mathrm{mM}$ EDTA, 3 mM EGTA and protease inhibitor cocktail (Roche Diagnostics, IN, U.S.A.) and collected to measure the production of MUC5AC protein (in 24-well culture plate). The total RNA was extracted for measuring the expression of MUC5AC gene (in 6-well culture plate) by using RT-PCR.

\section{MUC5AC mucin analysis using ELISA}

MUC5AC protein was measured by using ELISA. Cell lysates were prepared with PBS at 1:10 dilution, and $100 \mu \mathrm{l}$ of each sample was incubated at $42^{\circ} \mathrm{C}$ in a 96-well plate, until dry. Plates were washed three times with PBS and blocked with $2 \%$ BSA (fraction V) for 1 h at room temperature. Plates were again washed three times with PBS and then incubated with $100 \mu \mathrm{l}$ of $45 \mathrm{M} 1$, a mouse monoclonal MUC5AC antibody (NeoMarkers, CA, U.S.A.) (1:200), which was diluted with PBS containing $0.05 \%$ Tween 20 and dispensed into each well. After $1 \mathrm{~h}$, the wells were washed three times with PBS, and $100 \mu$ of horseradish peroxidase-goat anti-mouse lgG conjugate $(1: 3,000)$ was dispensed into each well. After $1 \mathrm{~h}$, plates were washed three times with PBS. Color reaction was developed with 3,3',5,5'-tetramethylbenzidine (TMB) peroxide solution and stopped with $1 \mathrm{~N} \mathrm{H}_{2} \mathrm{SO}_{4}$. Absorbance was read at $450 \mathrm{~nm}$.

\section{Total RNA isolation and RT-PCR}

Total RNA was isolated by using Easy-BLUE Extraction Kit (INTRON Biotechnology, Inc. Kyung-gi-do, Korea) and reverse transcribed by using AccuPower RT Premix (BIONEER Corporation, Daejeon, Korea) according to the manufacturer's instructions. $2 \mu \mathrm{g}$ of total RNA was primed with $1 \mu \mathrm{g}$ of oligo (dT) in a final volume of $50 \mu \mathrm{l}$ (RT reaction). $2 \mu$ of RT reaction product was PCR amplified in a $25 \mu \mathrm{l}$ by using Thermorprime Plus DNA Polymerase (ABgene, Rochester, NY, U.S.A.). Primers for MUC5AC were (forward) 5'-TGA TCA TCC AGC AGG GCT-3' and (reverse) 5'-CCG AGC TCA GAG GAC ATA TGG G-3'. The size of expected fragment amplified by PCR was 458 bp. As quantitative controls, primers for Rig/S15 rRNA, which encodes a small ribosomal subunit protein, a housekeeping gene that was constitutively expressed, were used. Primers for Rig/S15 were (forward) 5'-TTC CGC AAG TTC ACC TAC C-3' and (reverse) 5'-CGG GCC GGC CAT GCT TTA CG-3'. The size of expected fragment amplified by PCR was $361 \mathrm{bp}$. The PCR mixture was denatured at $94^{\circ} \mathrm{C}$ for 2 min followed by 40 cycles at $94^{\circ} \mathrm{C}$ for 30 $\mathrm{s}, 60^{\circ} \mathrm{C}$ for $30 \mathrm{~s}$ and $72^{\circ} \mathrm{C}$ for $45 \mathrm{~s}$. After PCR, $5 \mu$ of PCR products were subjected to $1 \%$ agarose gel electrophoresis and visualized with ethidium bromide under a transilluminator.

\section{Statistics}

Means of individual group were converted to percent control and expressed as mean \pm S.E.M. The difference between groups was assessed using one-way ANOVA and Student's t-test for unpaired samples. $p<0.05$ was considered as significantly different. 


\section{RESULTS}

\section{Effect of platycodin D on EGF-induced MUC5AC mucin production from $\mathrm{NCl}-\mathrm{H} 292$ cells}

As can be seen in Fig. 1, platycodin D inhibited EGF-induced MUC5AC mucin production. The amounts of MUC5AC mucin in the cells of platycodin D-treated cultures were $100 \pm$ $7 \%, 268 \pm 18 \%, 273 \pm 15 \%, 258 \pm 27 \%$ and $105 \pm 6 \%$ for control, EGF $25 \mathrm{ng} / \mathrm{ml}$ only, platycodin D $10^{-6} \mathrm{M}+\mathrm{EGF}$, platycodin $\mathrm{D} 10^{-5} \mathrm{M}+\mathrm{EGF}$ and platycodin $\mathrm{D} 10^{-4} \mathrm{M}+$ EGF, respectively (Fig. 1).

\section{Effect of platycodin D on PMA-induced MUC5AC mucin production from $\mathrm{NCl}-\mathrm{H} 292$ cells}

As can be seen in Fig. 2, platycodin D also inhibited PMA-induced MUC5AC mucin production, dose-dependently. The amounts of MUC5AC mucin in the cells of platycodin D-treated cultures were $100 \pm 10 \%, 378 \pm 29 \%, 392 \pm$ $35 \%, 135 \pm 8 \%$ and $121 \pm 9 \%$ for control, PMA $10 \mathrm{ng} / \mathrm{m}$ only, platycodin D $10^{-6} \mathrm{M}+\mathrm{PMA}$, platycodin $\mathrm{D} 10^{-5} \mathrm{M}+$ PMA and platycodin $D 10^{-4} \mathrm{M}+\mathrm{PMA}$, respectively (Fig. 2).

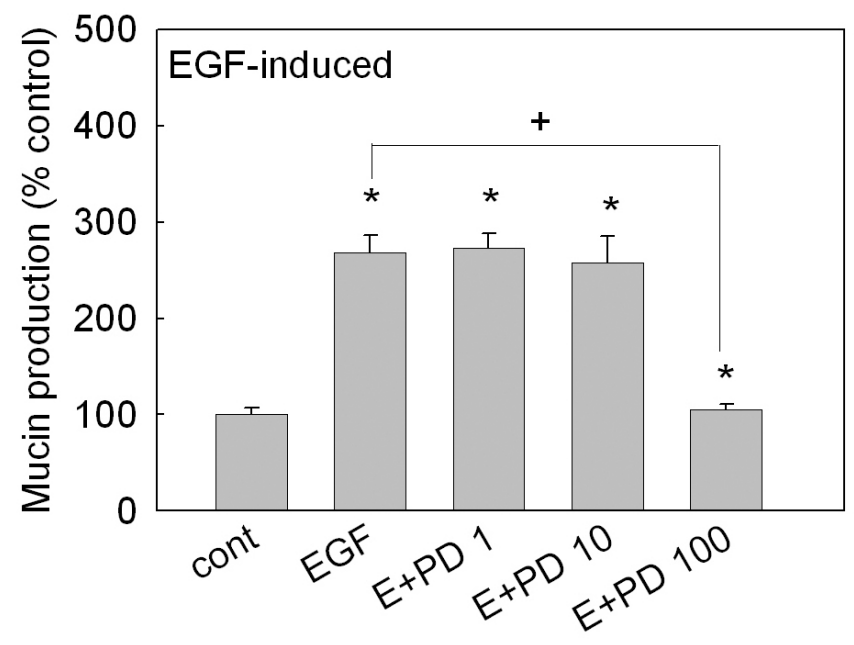

\section{Treatment}

Fig. 1. Effect of platycodin D on EGF-induced MUC5AC mucin production from $\mathrm{NCl}-\mathrm{H} 292$ cells. $\mathrm{NCl}-\mathrm{H} 292$ cells were pretreated with varying concentrations of platycodin $D$ for 30 min and then stimulated with EGF $(25 \mathrm{ng} / \mathrm{ml})$ for $24 \mathrm{~h}$. Cell lysates were collected for measurement of MUC5AC mucin production by ELISA. Each bar represents a mean \pm S.E.M. of 3-4 culture wells in comparison with that of control set at $100 \%$. *Significantly different from control $(p<0.05)$. + Significantly different from EGF alone $(p<0.05)$ (cont: control, PD: platycodin D, concentration unit is $\mu \mathrm{M})$.

\section{Effect of platycodin D on TNF-a-induced MUC5AC mucin production from $\mathrm{NCl}-\mathrm{H} 292$ cells}

As can be seen in Fig. 3, platycodin D inhibited TNF- $\alpha$ induced MUC5AC mucin production, dose-dependently. The amounts of MUC5AC mucin in the cells of platycodin D-treated cultures were $100 \pm 6 \%, 300 \pm 27 \%, 289 \pm 30 \%$, $210 \pm 23 \%$ and $150 \pm 7 \%$ for control, TNF- $\alpha 0.2 \mathrm{nM}$ only, platycodin $\mathrm{D} 10^{-6} \mathrm{M}+\mathrm{TNF}-\alpha$, platycodin $\mathrm{D} 10^{-5} \mathrm{M}+$ TNF- $\alpha$ and platycodin D $10^{-4} \mathrm{M}+\mathrm{TNF}-\alpha$, respectively (Fig. 3).

\section{Effect of platycodin D on MUC5AC gene expression induced by EGF, PMA, and TNF-a from NCl-H292 cells}

As can be seen in Fig. 4, platycodin $D$ at the concentration of $10^{-4} \mathrm{M}$ inhibited MUC5AC gene expression induced by EGF, PMA and TNF- $\alpha$, respectively (Fig. 4).

\section{DISCUSSION}

Although the root of Platycodon grandiflorum was used for the control of inflammatory airway diseases in traditional oriental medicine, there is no report about the action of platycodin $\mathrm{D}$ on the airway diseases except the only re-

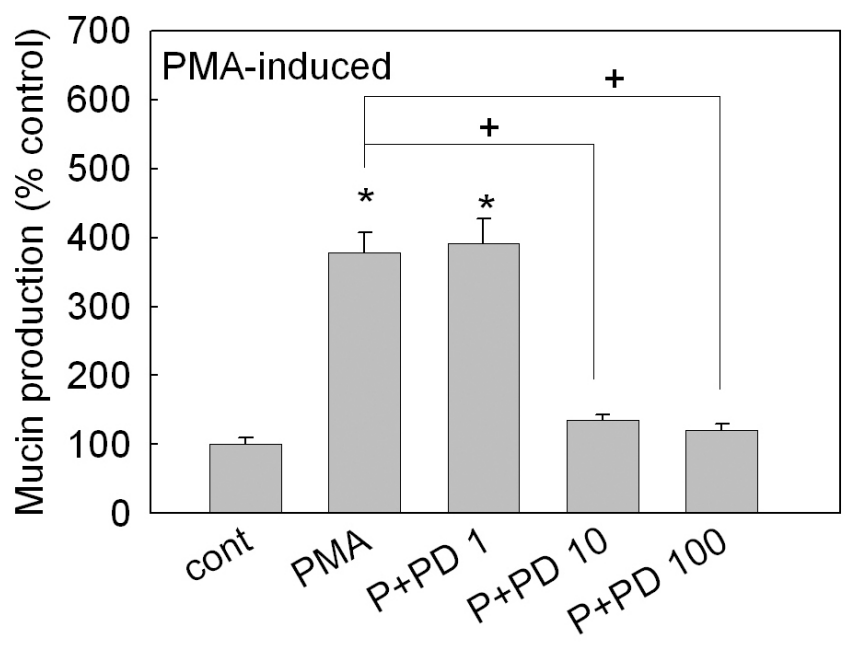

\section{Treatment}

Fig. 2. Effect of platycodin D on PMA-induced MUC5AC mucin production from $\mathrm{NCl}-\mathrm{H} 292$ cells. $\mathrm{NCl}-\mathrm{H} 292$ cells were pretreated with varying concentrations of platycodin $\mathrm{D}$ for $30 \mathrm{~min}$ and then stimulated with PMA (10 ng/ml) for $24 \mathrm{~h}$. Cell lysates were collected for measurement of MUC5AC mucin production by ELISA. Each bar represents a mean \pm S.E.M. of 3-4 culture wells in comparison with that of control set at $100 \%$. *Significantly different from control $(p<0.05)$. + Significantly different from PMA alone $(p<0.05)$ (cont: control, PD: platycodin D, concentration unit is $\mu \mathrm{M})$. 


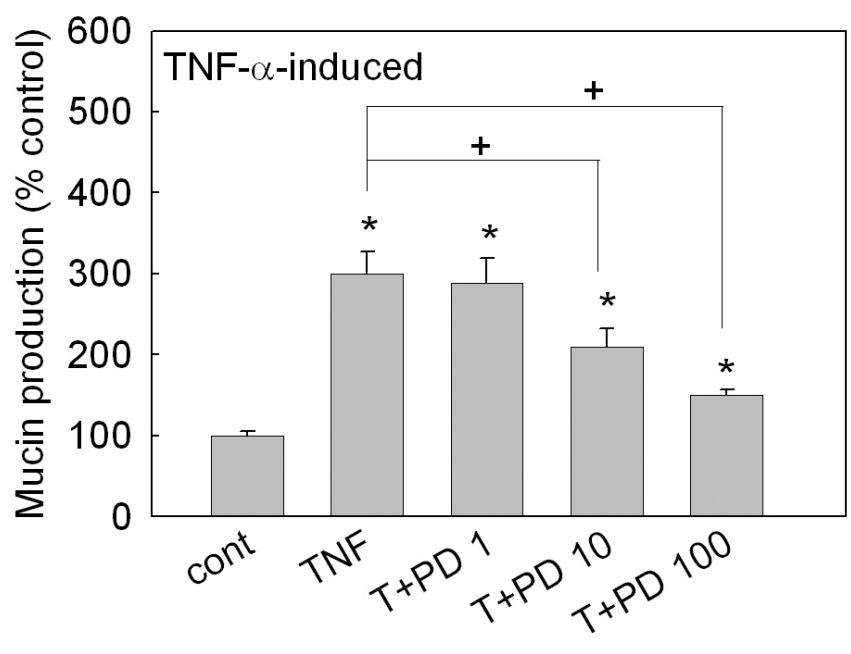

Treatment

Fig. 3. Effect of platycodin D on TNF- $\alpha$-induced MUC5AC mucin production from $\mathrm{NCl}-\mathrm{H} 292$ cells. $\mathrm{NCl}-\mathrm{H} 292$ cells were pretreated with varying concentrations of platycodin $\mathrm{D}$ for $30 \mathrm{~min}$ and then stimulated with TNF- $\alpha(0.2 \mathrm{nM})$ for $24 \mathrm{~h}$. Cell lysates were collected for measurement of MUC5AC mucin production by ELISA. Each bar represents a mean \pm S.E.M. of 3-4 culture wells in comparison with that of control set at $100 \%$. *Significantly different from control $(p<0.05)$. + Significantly different from TNF- $\alpha$ alone $(p<0.05)$ (cont: control, PD: platycodin D, concentration unit is $\mu \mathrm{M})$.

port that platycodin D and D3 stimulated mucin release from rat and hamster tracheal surface epithelial cell culture and also from intact rat trachea upon nebulization, by Shin and his colleagues (Shin et al., 2002). On the other hand, it was reported that MUC5AC was mainly expressed in goblet cells in the airway surface epithelium among the diverse genes coding human mucins (Rogers and Barnes, 2006). Takeyama and his colleagues reported that epidermal growth factor (EGF) regulated MUC5AC gene expression in the lung. According to their reports, MUC5AC mRNA expression was increased after ligand binding to the EGF receptor and activation of the MAPK (mitogen-activated protein kinase) cascade (Takeyama et al., 1999; Takeyama et al., 2000). Also, phorbol 12-myristate 13-acetate (PMA) acts as an alternative stimulus to the endogenous activator of protein kinase $C$ (PKC), diacylglycerol (DAG) and a model inflammatory stimulant that can modulate a variety of cellular events, including gene transcription (Hewson et al., 2004), cell growth and differentiation (Park et al., 2002). Especially, PMA was reported to induce MUC5AC gene expression in $\mathrm{NCl}-\mathrm{H} 292$ cells (Hewson et al., 2004). TNF- $\alpha$ is a stimulator of secretion and gene expression of mucin in the airway epithelium (Fisher et al., 1999; Shao et

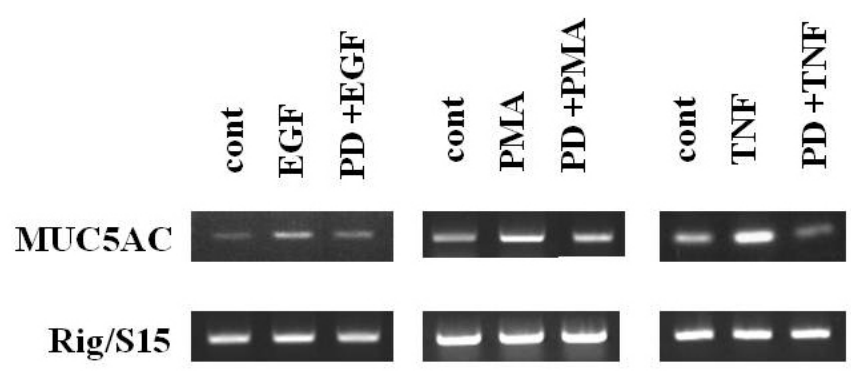

Fig. 4. Effects of platycodin D on EGF-, PMA- and TNF- $\alpha-$ induced MUC5AC gene expression from NCl-H292 cells. $\mathrm{NCl}-\mathrm{H} 292$ cells were pretreated with platycodin $\mathrm{D}(100 \mu \mathrm{M})$ for $30 \mathrm{~min}$ and then stimulated with EGF $(25 \mathrm{ng} / \mathrm{ml})$, PMA (10 $\mathrm{ng} / \mathrm{ml})$ and TNF- $\alpha(0.2 \mathrm{nM})$ for $24 \mathrm{~h}$, respectively. MUC5AC gene expression was measured by RT-PCR. As quantitative control, Rig/S15 rRNA, which encodes a small ribosomal subunit protein, a housekeeping gene that was constitutively expressed, was used (cont: control, PD: platycodin D).

al., 2003; Song et al., 2003). TNF- $\alpha$ levels in sputum were reported to be increased, with further increases during exacerbation of diseases (Chung, 2001; Cohn et al., 2002). TNF- $\alpha$ converting enzyme (TACE) mediated MUC5AC mucin expression in cultured human airway epithelial cells (Shao et al., 2003) and TNF- $\alpha$ induced MUC5AC gene expression in normal human airway epithelial cells (Song et al., 2003). It also induced mucin secretion from guinea pig tracheal epithelial cells (Fisher et al., 1999). On the basis of these reports, we tried to examine the potential effect of platycodin D on MUC5AC mucin production and gene expression induced by EGF, PMA and TNF- $\alpha$ from NCl-H292 cells, a human pulmonary mucoepidermoid cell line, which are frequently used for the purpose of elucidating intracellular signaling pathways involved in airway mucin production and gene expression (Li et al., 1997; Takeyama et al., 1999; Shao et al., 2003). As shown in results, platycodin $D$ inhibited the production of MUC5AC mucin protein induced by EGF, PMA and TNF- $\alpha$, respectively. Also, platycodin D suppressed the expression of MUC5AC mucin gene induced by the same stimulators. These results suggest that platycodin $\mathrm{D}$ can regulate mucin gene expression and production of mucin protein, by directly acting on human airway epithelial cells. However, Shin et al. reported that the effect of platycodin D3 on mucin release was more potent than that of adenosine triphosphate (ATP), a wellknown mucin secretagogue, and they suggested platyco$\operatorname{din} \mathrm{D}$ and $\mathrm{D}_{3}$ might be useful as expectorants for the treatment of various airway diseases (Shin et al., 2002). Therefore, it is to be elucidated why platycodin $D$ can stimulate the secretion of airway mucin with the activity of suppression of airway mucin production and gene expression, 
through future research. The underlying mechanism of action of platycodin D on MUC5AC production and gene expression are not clear at present, although we are trying to investigate whether platycodin D acts as potential regulators of the MAPK (mitogen-activated protein kinase) cascade after ligand binding to the EGF receptor and/or potential regulators of NF-kB signaling pathway, in mucinproducing $\mathrm{NCl}-\mathrm{H} 292$ cells. Taken together, the inhibitory action of platycodin D on airway mucin production and gene expression might explain, at least in part, the traditional use of Platycodon grandiflorum as an anti-inflammatory agent for the control of airway inflammatory diseases, in oriental medicine. We suggest it is valuable to find the natural products that have specific inhibitory effect on mucin production and/or gene expression - in view of both basic and clinical sciences - and to search the optimal chemical moieties derived from the chemical structure of platycodin $D$ which can be useful as an efficacious regulator for mucin production in hypersecretory status of diverse chronic airway diseases, through further studies.

\section{ACKNOWLEDGMENTS}

This study was partly supported by 2009 grant of Technology Development Program for Agriculture and Forestry, Ministry for Food, Agriculture, Forestry and Fisheries, Republic of Korea.

\section{REFERENCES}

Ahn, K. S., Hahn, B. S., Kwack, K., Lee, E. B. and Kim, Y. S. (2006). Platycodin D-induced apoptosis through nuclear factor-kappaB activation in immortalized keratinocytes. Eur. J. Pharmacol. 537, 1-11.

Chung, J. W., Noh, E. J., Zhao, H. L., Sim, J. S., Ha, Y. W., Shin, E. M., Lee, E. B., Cheong, C. S. and Kim, Y. S. (2008). Anti-inflammatory activity of prosapogenin methyl ester of platycodin $\mathrm{D}$ via nuclear factor-kappaB pathway inhibition. Biol. Pharm. Bull. 31, 2114-2120.

Chung, K. F. (2001). Cytokines in chronic obstructive pulmonary disease. Eur. Respir. J. Suppl. 34, 50-59.

Cohn, L., Whittaker, L., Niu, N. and Homer, R. J. (2002). Cytokine regulation of mucus production in a model of allergic asthma. Novartis. Found. Symp. 248, 201-213.

Ellis, E. F. (1985). Asthma in childhood. J. Allergy. Clin. Immunol. 72(Suppl), 526-539.

Fischer, B. M., Rochelle, L. G., Voynow, J. A., Akley, N. J. and Adler, K. B. (1999). TNF-alpha stimulates mucin secretion and cyclic GMP production by guinea pig tracheal epithelial cells in vitro. Am. J. Respir. Cell. Mol. Biol. 20, 413-422.

Heo, H. J., Kim, C., Lee, H. J., Kim, Y. S., Kang, S. S., Seo, U. K., Kim, Y. H., Park, Y. C., Seok, J. H. and Lee, C. J. (2007a). Carbenoxolone and triterpenoids inhibited mucin secretion from airway epithelial cells. Phytother. Res. 21, 462-465.
Heo, H. J., Lee, H. J., Kim, Y. S., Kang, S. S., Son, K. H., Seok, J. H., Seo, U. K. and Lee, C. J. (2007b). Effects of baicalin and wogonin on mucin release from cultured airway epithelial cells. Phytother. Res. 21, 1130-1134.

Heo, H. J., Lee, S. Y., Lee, M. N., Lee, H. J., Seok, J. H. and Lee, C. J. (2009). Genistein and curcumin suppress epidermal growth factor-induced MUC5AC mucin production and gene expression from human airway epithelial cells. Phytother. Res. 23, 1458-1461.

Hewson, C. A., Edbrooke, M. R. and Johnston, S. L. (2004). PMA induces the MUC5AC respiratory mucin in human bronchial epithelial cells, via PKC, EGF/TGF-alpha, Ras/Raf, MEK, ERK and Sp1-dependent mechanisms. J. Mol. Biol. 344, 683-695.

Jang, I. M. (2003). Treatise on asian herbal medicines. Haksulpyunsu-kwan in Research institute of natural products of Seoul National University, Seoul. pp. 2748.

Kim, M. O., Moon, D. O., Choi, Y. H., Shin, D. Y., Kang, H. S., Choi, B. T., Lee, J. D., Li, W. and Kim, G. Y. (2008). Platycodin $D$ induces apoptosis and decreases telomerase activity in human leukemia cells. Cancer Lett. 261, 98-107.

Kim, Y. P., Lee, E. B., Kim, S. Y., Li, D., Ban, H. S., Lim, S. S., Shin, K. H. and Ohuchi, K. (2001). Inhibition of prostaglandin E2 production by platycodin $D$ isolated from the root of Platycodon grandiflorum. Planta Med. 67, 362-364.

Lee, C. J., Lee, J. H., Seok, J. H., Hur, G. M., Park, J. S., Bae, S., Lim, J. H. and Park, Y. C. (2004a). Effects of betaine, coumarin and flavonoids on mucin release from cultured hamster tracheal surface epithelial cells. Phytother. Res. 18, 301-305.

Lee, C. J., Lee, J. H., Seok, J. H., Hur, G. M., Park, Y. C., Seol, I. C. and Kim, Y. H. (2003). Effects of baicalein, berberine, curcumin and hesperidin on mucin release from airway goblet cells. Planta Med. 69, 523-526.

Lee, C. J., Seok, J. H., Hur, G. M., Lee, J. H., Park, J. S., Seol, I. C. and Kim, Y. H. (2004b). Effects of ursolic acid, betulin and sulfur-containing compounds on mucin release from airway goblet cells. Planta Med. 70, 1119-1122.

Li, J. D., Dohrman, A. F., Gallup, M., Miyata, S., Gum, J. R., Kim, Y. S., Nadel, J. A., Prince, A. and Basbaum, C. B. (1997). Transcriptional activation of mucin by Pseudomonas aeruginosa lipopolysaccharide in the pathogenesis of cystic fibrosis lung disease. Proc. Natl. Acad. Sci. U S A 94, 967 $-972$.

Park, S. J., Kang, S. Y., Kim, N. S. and Kim, H. M. (2002). Phosphatidylinositol 3-kinase regulates PMA-induced differentiation and superoxide production in HL-60cells. Immunopharmacol. Immunotoxicol. 24, 211-226.

Rogers, D. F. and Barnes, P. J. (2006). Treatment of airway mucus hypersecretion. Ann. Med. 38, 116-125.

Shao, M. X., Ueki, I. F. and Nadel, J. A. (2003). TNF-alpha converting enzyme mediated MUC5AC mucin expression in cultured human airway epithelial cells. Proc. Natl. Acad. Sci. U S A 100, 11618-11623.

Shin, C. Y., Lee, W. J., Lee, E. B., Choi, E. Y. and Ko, K. H. (2002). Platycodin D and D3 increase airway mucin release in vivo and in vitro in rats and hamsters. Planta Med. 68, 221-225.

Song, K. S., Lee, W. J., Chung, K. C., Koo, J. S., Yang, E. J., Choi, J. Y. and Yoon, J. H. (2003). IL-1beta and TNF-alpha induced MUC5AC overexpression through a mechanism 
involving ERK/p38 mitogen-activated protein kinase-MSK1CREB activation in human airway epithelial cells. J. Biol. Chem. 278, 23243-23250.

Takeyama, K., Dabbagh, K., Jeong, Shim, J., Dao-Pick, T., Ueki, I. F. and Nadel, J. A. (2000). Oxidative stress causes mucin synthesis via transactivation of epidermal growth factor receptor: role of neutrophils. J. Immunol. 164, 15461552.
Takeyama, K., Dabbagh, K., Lee, H., Agusti, C., Lausier, J. A., Ueki, I. F., Grattan, K. M. and Nadel, J. A. (1999). Epidermal growth factor system regulates mucin production in airways. Proc. Natl. Acad. Sci. U S A 6, 3081-3086.

Yu, J. S. and Kim, A. K. (2010). Platycodin D induces apoptosis in MCF-7 human breast cancer cells. J. Med. Food. 13, 298305. 